\title{
Genetic Structure of Xiphinema pachtaicum and $X$. index Populations Based on Mitochondrial DNA Variation
}

\author{
Carlos Gutiérrez-Gutiérrez, Pablo Castillo, Carolina Cantalapiedra-Navarrete, \\ Blanca B. Landa, Sofie Derycke, and Juan E. Palomares-Rius
}

First, second, third, fourth, and sixth authors: Instituto de Agricultura Sostenible (IAS), Consejo Superior de Investigaciones Científicas (CSIC), Apdo. 4084, 14080 Córdoba, Spain; and fifth author: Department of Biology, Marine Biology Section, Ghent University, Krijgslaan 281, S8, 9000 Ghent, Belgium.

Accepted for publication 2 May 2011.

\begin{abstract}
Gutiérrez-Gutiérrez, C., Castillo, P., Cantalapiedra-Navarrete, C., Landa, B. B., Derycke, S., and Palomares-Rius, J. E. 2011. Genetic structure of Xiphinema pachtaicum and $X$. index populations based on mitochondrial DNA variation. Phytopathology 101:1168-1175.

The dagger nematodes Xiphinema pachtaicum and $X$. index are two of the most widespread and frequently occurring Xiphinema spp. coinfesting vineyards and other crops and natural habitats worldwide. Sexual reproduction is rare in these species. The primary objective of this study was to determine the genetic structure of $X$. pachtaicum and $X$. index populations using eight and seven populations, respectively, from different "wine of denomination of origin (D.O.) zones" in Spain and Sardinia (Italy), by studying mitochondrial (cytochrome oxidase c subunit 1 or COI) and nuclear (D2-D3 expansion segments of 28S rDNA)

markers. Both Xiphinema spp. showed low intraspecific divergence among $C O I$ sequences, ranging from $0.2 \%$ (1 base substitution) to $2.3 \%$ (10 substitutions) in X. pachtaicum and from $0.2 \%$ (1 base substitution) to $0.4 \%$ ( 2 substitutions) in $X$. index. Population genetic structure was strong for both species. Nevertheless, molecular differences among grapevinegrowing areas were not significant, and intrapopulation diversity was very low. It is hypothesized that this genetic homogeneity in the nematode populations reflects their predominant parthenogenetic reproduction mode and low dispersal abilities. Our results also show that X. pachtaicum populations in Spain have possibly been established from two different populations of origin. Results also demonstrated that the two DNA regions studied are suitable diagnostic markers for $X$. index and $X$. pachtaicum.
\end{abstract}

Dagger nematodes of the genus Xiphinema are phytopathogenic species that damage a wide range of wild and cultivated plants through direct feeding on root cells and transmission of some plant viruses (50). This transmission is governed by a marked specificity between plant viruses and their Xiphinema spp. vectors. In fact, only 9 of the $\approx 250$ known species of Xiphinema have been shown to transmit nepoviruses (genus Nepovirus, family Comoviridae) (11). The Xiphinema americanum group, which comprises a complex of $\approx 50$ cosmopolitan species, seems to be one of the most difficult Xiphinema groups for diagnosis (9) and it includes the vectors of several important plant viruses, including Tobacco ringspot virus, Tomato ringspot virus, Cherry rasp leaf virus, and Peach rosette mosaic virus.

$X$. pachtaicum belongs to the $X$. americanum group and is the most widespread and frequently occurring Xiphinema sp. in agricultural land, shrub land, forest, and permanent pastures worldwide (27). In Spain, it is the most abundant Xiphinema sp. in vineyards and stone-fruit orchards $(1,19)$. This species has fewer ecological requirements and a wider range of habitats and hosts than the other Xiphinema spp. $(5,33)$. Reports of $X$. pachtaicum outside the Mediterranean Basin and Central Asia have been considered to be introductions by human activities, as was shown for those from the United States, Australia, and Chile $(26,27,39,41)$.

Corresponding author: J. E. Palomares-Rius;

E-mail address: palomaresje@ias.csic.es

* The $e$-Xtra logo stands for "electronic extra" and indicates that Figure 2 appears in color online.

doi:10.1094/PHYTO-07-10-0194

(C) 2011 The American Phytopathological Society
Similarly, $X$. index is also a worldwide-distributed nematode in grapevine-growing areas (50). This species is thought to have been dispersed from the Middle East into other grapevine-growing regions of the world in soil accompanying propagation material and, today, has become an invasive agricultural soilborne pathogen $(4,52) . X$. index severely damages grapevines by direct parasitism and as a vector of Grapevine fanleaf virus. Grapevine fanleaf is the most severe virus-induced diseases of grapevines worldwide and can cause important economic losses by reducing yield $\leq 80 \%$ and affecting fruit quality (29). In Spain, $X$. index is widespread in grapevine-growing areas in a wide range of soil textures and $\mathrm{pH}$, even in soils with high a percentage of carbonates (2).

The prevalence of $X$. pachtaicum and the importance of $X$. index as a virus vector, together with the possibility of the latter being an introduced species and occupying a more restricted habitat than $X$. pachtaicum, make them interesting nematode species for the study of population genetics of plant-parasitic nematodes. Results from a recent phylogeographic study of $X$. index using the cytochrome B gene $(c y t B)$ showed that all haplotypes were shared among populations from Cyprus, Israel, Palestine, and Iran. Conversely, nematode populations from America (Chile and the United States) and Europe (France, Greece, Italy, and Spain) shared only one haplotype, suggesting that the haplotype distribution in $X$. index identified by $c y t B$ may be paralleled to the history of grapevine cultivation (53). Several studies have been conducted to determine the genetic variability and structure of soilborne plant pathogens, including bacteria, fungi, plant-parasitic nematodes, and viruses $(32,35,40)$. Identification of biotypes or strains of plant pathogens (i.e., population variants) has important implications for understanding evolutionary processes, such as development of parasitic races, adaptation to host defenses, and development of resistance to pesticides 
(45). Knowledge of the genetic structure of plant pathogens may offer insights into the future evolutionary potential of the pathogen populations (30), as well as provide insights for their management using resistant cultivars (37). In plant-parasitic nematodes, intra- and interpopulation genetic variability as well as transfer of genetic material between populations by dispersal followed by successful reproduction (gene flow) at various spatial scales have been scarcely studied (37). However, recent population genetic studies have been conducted in amphimictic species such as Heterodera schachtii (37), Globodera pallida (36), and Bursaphelenchus xylophilus (54). Asexually reproducing root-knot nematodes (i.e., some Meloidogyne spp.) (17,24), and mainly parthenogenetic virus-vector nematodes (i.e., $X$. index) (52) do not undergo regular genetic recombination, and genetic variation results mainly from accumulation of mutations.

Mitochondrial DNA analysis has proven to be a powerful tool for assessing intraspecific phylogenetic patterns in plant-parasitic nematodes (24). The protein-coding mitochondrial gene, cytochrome oxidase c subunit 1 (COI), has been shown to be applicable for population-based studies in a range of invertebrates (22), for phylogeny of plant-parasitic nematodes (34), and for genetic barcoding (14). In contrast, nuclear genes such as the D2-D3 expansion segments of the $28 \mathrm{~S}$ ribosomal DNA have a low mutation rate and have been successfully used for species diagnosis and resolving phylogenetic relationships among closely related nematode species $(46,47)$. The application of molecular methods for plant-parasitic nematode population structure and systematics has revealed that long-time assumed single species are, in fact, complexes of cryptic species (i.e., species that are genetically distinct but share morphological similarities) $(19,20,46)$.

The objectives of this research were to determine the population genetic structure and history of $X$. pachtaicum and $X$. index, and to investigate whether the molecular markers used can reliably identify both species. Both nematode species have a widespread distribution in grapevine-growing areas despite low dispersal abilities. Sampling design was performed on areas of leading grapevine-growing areas in Spain and Sardinia (Italy), and within a commercial grapevine orchard in southern Spain, to determine the potential gene flow between grapevine areas and the genetic diversity of the populations within these areas. Furthermore, both species are very difficult to distinguish using morphological features, and their identification requires sufficient expertise and time. Therefore, a molecular tool may greatly enhance the accuracy and speed of species-level identification.

\section{MATERIALS AND METHODS}

Field sampling and nematode populations. Eight populations of $X$. pachtaicum were sampled at eight locations in Spain (Table 1; Fig. 1). Seven populations of $X$. index were sampled at five locations in Spain and two locations at southern Sardinia Island, Italy; these two samples were kindly provided by V. A. Prota, Università degli Studi, Sassari, Italy. In Spain, all samples but two were from vineyards and every province represented a "wine denomination of origin (D.O.) zone," including Condado de Huelva D.O. (Huelva province), Montilla-Moriles D.O. (Córdoba province), Jerez-Xérès-Sherry and Manzanilla-Sanlúcar de Barrameda D.O. (Cádiz province), Málaga D.O. (Málaga province), and Rioja D.O. (Logroño province). Córdoba-IAS and CórdobaAulaga populations were sampled on bitter orange at the Agricultural Research Station of the Institute of Sustainable AgricultureCSIC (Córdoba) and at a fallow soil near Córdoba, respectively (Table 1). Rioja (Rioja D.O.) and Frigiliana (Málaga D.O.) samples are well separated geographically from the other samples by ranges of mountains $(\approx 1,500 \mathrm{~m}$ high), while the remaining locations do not have obvious geographical barriers. For each sampled point, the geographic coordinates were recorded (Tables 1 and 2) by using a GPS II plus (Garmin Corporation, United Kingdom).

Additionally, the sample Moriles-393 (Córdoba province) was subsampled in three separate points of the commercial vineyard (at distances of 50 to $200 \mathrm{~m}$ ) to determine the genetic diversity within this field. Studied points in this field were selected according to the higher abundance of the targeted nematode species (X. pachtaicum or X. index) (P. Castillo, C. GutiérrezGutiérrez, J. Navas-Castillo, M. Teixeira Santos, B. B. Landa, and J. A. Navas-Cortés, unpublished data). In this field, for each subsample, the same number of specimens was collected $(n=9$ for $X$. pachtaicum and $n=13$ for $X$. index).

Nematode extraction and identification. Nematodes were extracted from soil samples by the sieving method (18). Ten specimens from every location were used for correct species identification by light microscopy using morphology and morphometrics (19). For that, nematodes were killed by gentle heating, fixed in a solution of $4 \%$ formaldehyde $+1 \%$ propionic acid, and processed to pure glycerin using Seinhorst's (43) method. Specimens were examined using a Zeiss III compound microscope with Nomarski differential interference contrast at powers up to $\times 1,000$ magnification. Measurements were made using a drawing tube attached to a light microscope.

TABLE 1. Xiphinema pachtaicum distribution of mitochondrial DNA COI haplotypes and D2-D3 sequences among sampling locations

\begin{tabular}{|c|c|c|c|c|c|c|c|c|c|c|c|c|}
\hline \multirow[b]{2}{*}{ Population localities } & \multirow[b]{2}{*}{ Coordinates } & \multicolumn{2}{|c|}{ Accession numbers ${ }^{\mathrm{a}}$} & \multicolumn{6}{|c|}{ COI haplotypes } & \multirow[b]{2}{*}{$n^{\mathrm{b}}$} & \multirow[b]{2}{*}{$h^{\mathrm{b}}$} & \multirow[b]{2}{*}{$\pi^{\mathrm{b}}$} \\
\hline & & $\mathrm{COI}$ & D2-D3 & PA & PA1 & PB & $\mathrm{PC}$ & PD & PE & & & \\
\hline Córdoba-IAS & $37^{\circ} 51^{\prime} 37.28^{\prime \prime} \mathrm{N}$ & HM921369 (PA) & HM921389 (PA) (Pach7) & & & & & & & & & \\
\hline (Córdoba province, Spain) & $-4^{\circ} 47^{\prime \prime} 3.27^{\prime \prime} \mathrm{W}$ & HM921370 (PB) & HM921390 (PB) (Pach5) & 8 & - & 4 & - & - & - & 12 & 0.702 & 4.364 \\
\hline Moriles-393 & $37^{\circ} 27^{\prime} 21.99^{\prime \prime} \mathrm{N}$ & & & & & & & & & & & \\
\hline 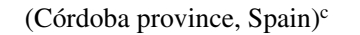 & $-4^{\circ} 36^{\prime} 42.52^{\prime \prime} \mathrm{W}$ & HM921371 (PC) & HM921391(PC) (Pach3) & - & - & - & 27 & - & - & 27 & 0 & 0 \\
\hline Frigiliana & $36^{\circ} 47^{\prime} 38.09^{\prime \prime} \mathrm{N}$ & & & & & & & & & & & \\
\hline (Málaga province, Spain) & $-3^{\circ} 54^{\prime} 43.87^{\prime \prime} \mathrm{W}$ & HM921372 (PA) & HM921392 (PA) (pach7) & 3 & - & - & - & - & - & 3 & 0 & 0 \\
\hline Jerez de la Frontera-401 & $36^{\circ} 22^{\prime} 55.19^{\prime \prime} \mathrm{N}$ & HM921373 (PA) & & & & & & & & & & \\
\hline (Cádiz province, Spain) & $-6^{\circ} 11^{\prime} 18.89^{\prime \prime} \mathrm{W}$ & HM921374 (PD) & HM921393 (PD) (Pach2) & 4 & - & - & - & 1 & - & 5 & 0.497 & 1.200 \\
\hline $\begin{array}{l}\text { Jerez de la Frontera-500 } \\
\text { (Cádiz province, Spain) }\end{array}$ & $\begin{array}{l}36^{\circ} 43^{\prime} 5.27^{\prime \prime} \mathrm{N} \\
-6^{\circ} 13^{\prime} 3.94^{\prime \prime} \mathrm{W}\end{array}$ & HM921375 (PE) & HM921394 (PE) (Pach4) & - & - & - & - & - & 12 & 12 & 0 & 0 \\
\hline $\begin{array}{l}\text { Trebujena-506, } \\
\text { (Cádiz province, Spain) }\end{array}$ & $\begin{array}{l}36^{\circ} 51^{\prime} 27.87^{\prime \prime} \mathrm{N} \\
-6^{\circ} 11^{\prime} 31.22^{\prime \prime} \mathrm{W}\end{array}$ & HM921376 (PA) & HM921395 (PA) (Pach1) & 8 & - & - & - & - & - & 8 & 0 & 0 \\
\hline $\begin{array}{l}\text { Bollullos par del Condado-484 } \\
\text { (Huelva province, Spain) }\end{array}$ & $\begin{array}{l}37^{\circ} 19^{\prime} 46.85^{\prime \prime} \mathrm{N} \\
-6^{\circ} 32^{\prime} 27.35^{\prime \prime} \mathrm{W}\end{array}$ & HM921378 (PA1) & HM921396 (PA1) (Pach6) & - & 8 & - & - & - & - & 8 & 0 & 0 \\
\hline $\begin{array}{l}\text { La Guardia-Rioja } \\
\text { (Logroño province, Spain) }\end{array}$ & $\begin{array}{l}42^{\circ} 32^{\prime} 29.6^{\prime \prime} \mathrm{N} \\
-2^{\circ} 34^{\prime} 4.25^{\prime \prime} \mathrm{W}\end{array}$ & HM921379 (PC) & HM921397 (PC) (Pach7) & - & - & - & 13 & - & - & 13 & 0 & 0 \\
\hline Total & $\ldots$ & $\ldots$ & $\ldots$ & 23 & 8 & 4 & 40 & 1 & 12 & 89 & $\ldots$ & \\
\hline
\end{tabular}

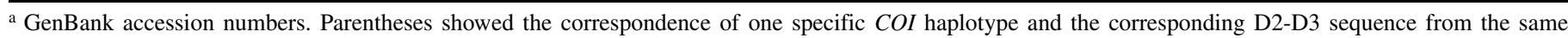
individual and the specific haplotype for D2-D3 region.

${ }^{\mathrm{b}}$ Haplotype diversity $(h)$ and nucleotide diversity $(\pi)$ for each location; $n=$ number of individuals analyzed.

c Population sampled in three places with high infestation levels in the same field. 
DNA extraction and polymerase chain reaction. Nematode genomic DNA was extracted from single adult females of each of the 15 Xiphinema populations. DNA extraction was performed as previously described (7). The portion of the COI gene was amplified as described by Derycke et al. (12) using primers JB3 ( $5^{\prime}$ TTTTTTGGGCATCCTGAGGTTTAT-3') and JB4.5 (5'-TAAA GAAAGAACATAATGAAAATG-3') for $X$. pachtaicum and primers COI1XIPFW (5'-GATTCTTCGGACATCCTGATG-3') and COI1XIPRV1 (5'-CGAATACAGCTCCTATA-3') for $X$. index. These latter primers were designed by the authors using $X$. index expressed sequence tag sequence from the GenBank database
(CV581361) and amplified the same COI region as the first primer set but yielded a slightly shorter fragment (491 versus 456 $\mathrm{bp}$, including primers). We additionally analyzed the D2-D3 region of 28S rDNA from nematode specimens having distinct COI haplotypes (except for sample Jerez de la Frontera-401) (Table 1), using primers D2A (5'-ACAAGTACCGTGAGGGA AAGTTG-3') and D3B (5'-TCGGAAGGAACCAGCTACTA-3') and amplification conditions described by Castillo et al. (7).

Single-strand conformation polymorphism analysis. In all, 3 to 39 COI polymerase chain reactions (PCRs) were processed for each Xiphinema population for single-strand conformation poly-

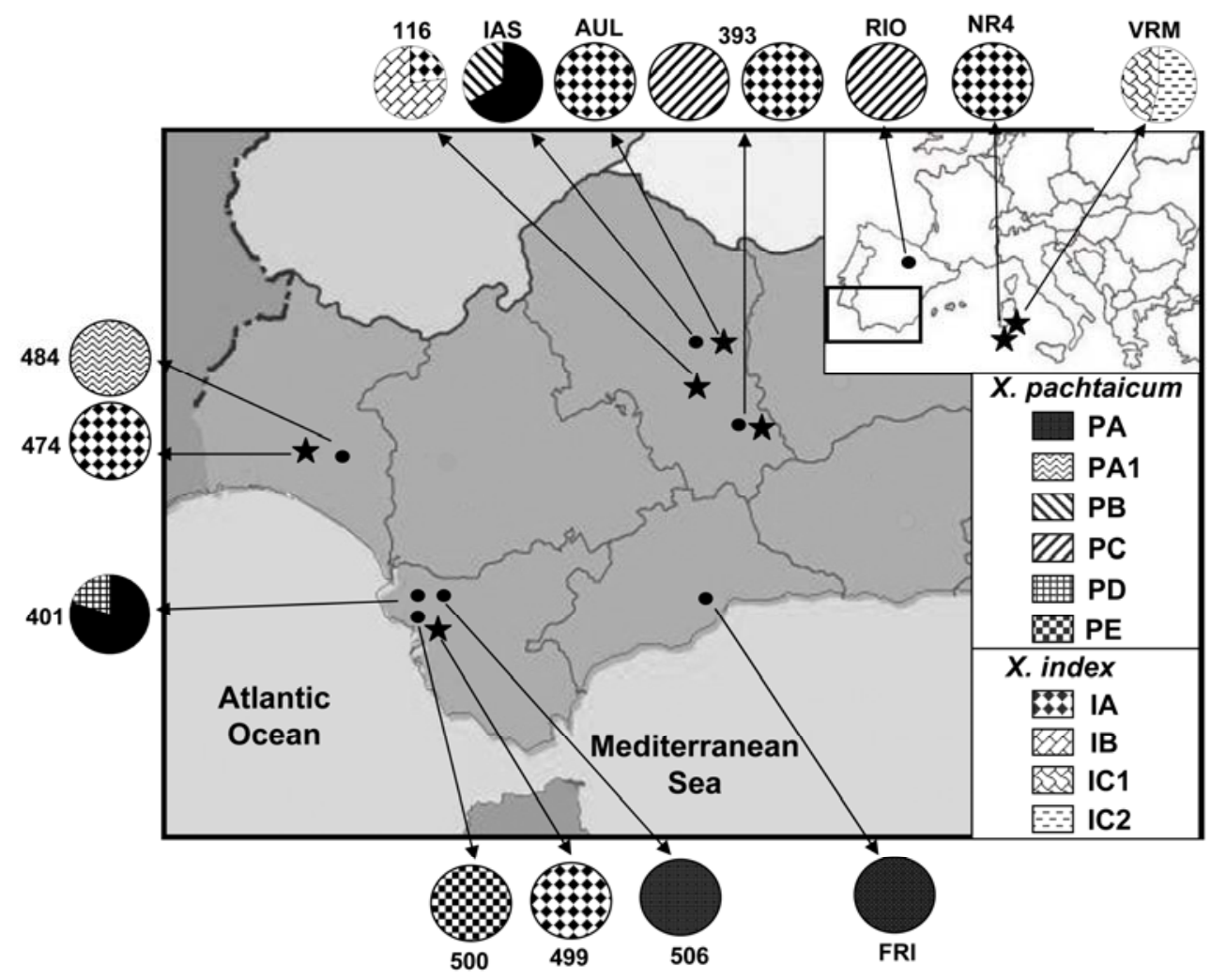

Fig. 1. Map of Iberian Peninsula and southern Europe showing geographic location and mitochondrial DNA haplotype frequencies of the populations of Xiphinema pachtaicum and $X$. index. Circles were divided proportionally to the number of different haplotypes found. Population codes: $116=$ Montemayor-116; IAS = Córdoba-IAS; AUL = Córdoba-Aulaga; 393 = Moriles-393; RIO = La Guardia-Rioja; NR4 = Parteolla-NR4; VRM = Trexenta-VRM; FRI = Frigiliana; $506=$ Trebujena-506; 499 = Jerez de la Frontera-499; 500 = Jerez de la Frontera-500; $401=$ Jerez de la Frontera-401; $474=$ Rociana-474; and 484 = Bollullos par del Condado-484. Dot symbol refers to $X$. pachtaicum, while star symbol refers to $X$. index populations.

TABLE 2. Xiphinema index distribution of mitochondrial DNA COI haplotypes and D2-D3 sequences among sampling locations

\begin{tabular}{|c|c|c|c|c|c|c|c|c|c|c|}
\hline \multirow[b]{2}{*}{ Population localities } & \multirow[b]{2}{*}{ Coordinates } & \multicolumn{2}{|c|}{ Accession numbers ${ }^{\mathrm{a}}$} & \multicolumn{4}{|c|}{ COI haplotypes } & \multirow[b]{2}{*}{$n^{\mathrm{b}}$} & \multirow[b]{2}{*}{$h^{\mathrm{b}}$} & \multirow[b]{2}{*}{$\pi^{\mathrm{b}}$} \\
\hline & & $\mathrm{COI}$ & D2-D3 & IA & IB & IC1 & IC2 & & & \\
\hline $\begin{array}{l}\text { Moriles-393 } \\
\text { (Córdoba province, Spain) }\end{array}$ & $\begin{array}{l}37^{\circ} 27^{\prime} 21.99^{\prime \prime} \mathrm{N}, \\
-4^{\circ} 36^{\prime} 42.52^{\prime \prime} \mathrm{W}\end{array}$ & HM921380 (IA) & HM921398 (IA) (Index1) & 39 & - & - & - & 39 & 0 & 0 \\
\hline (Córdoba province, Spain) & $-4^{\circ} 41^{\prime} 57.65^{\prime \prime} \mathrm{W}$ & HM921382 (IB) & HM921400 (IB) (Index1) & 3 & 10 & - & - & 13 & 0.465 & 0.769 \\
\hline $\begin{array}{l}\text { Córdoba-Aulaga } \\
\text { (Córdoba province, Spain) }\end{array}$ & $\begin{array}{l}37^{\circ} 53^{\prime} 36.66^{\prime \prime} \mathrm{N} \\
-4^{\circ} 43^{\prime} 20.13^{\prime \prime} \mathrm{W}\end{array}$ & HM921383 (IA) & HM921401 (IA) (Index1) & 13 & - & - & - & 13 & 0 & 0 \\
\hline $\begin{array}{l}\text { Rociana-474 } \\
\text { (Huelva province, Spain) }\end{array}$ & $\begin{array}{l}37^{\circ} 19^{\prime} 24.13^{\prime \prime} \mathrm{N}, \\
-6^{\circ} 36^{\prime} 48.96^{\prime \prime} \mathrm{W}\end{array}$ & HM921385 (IA) & HM921403 (IA) (Index1) & 13 & - & - & - & 13 & 0 & 0 \\
\hline $\begin{array}{l}\text { Parteolla-NR4 } \\
\text { (Sardinia, Italy) }\end{array}$ & $\begin{array}{l}39^{\circ} 22^{\prime} 55.07^{\prime \prime} \mathrm{N}, \\
-9^{\circ} 03^{\prime} 40.38^{\prime \prime} \mathrm{W}\end{array}$ & HM921386 (IA) & HM921404 (IA) (Index1) & 13 & - & - & - & 13 & 0 & 0 \\
\hline $\begin{array}{l}\text { Trexenta-VRM } \\
\text { (Sardinia, Italy) }\end{array}$ & $\begin{array}{l}39^{\circ} 31^{\prime} 32.42^{\prime \prime} \mathrm{N}, \\
-9^{\circ} 05^{\prime} 40.69^{\prime \prime} \mathrm{W}\end{array}$ & $\begin{array}{l}\text { HM921387 (IC1) } \\
\text { HM921388 (IC2) }\end{array}$ & $\begin{array}{l}\text { HM921405 (IC1) (Index1) } \\
\text { HM921406 (IC2 (Index1) }\end{array}$ & - & - & 6 & 7 & 13 & 0.873 & 1.077 \\
\hline Total & $\ldots$ & $\ldots$ & $\ldots$ & 94 & 10 & 6 & 7 & 117 & $\ldots$ & $\ldots$ \\
\hline
\end{tabular}

${ }^{a}$ GenBank accession numbers. Parentheses showed the correspondence of one specific COI haplotype and the corresponding D2-D3 sequence from the same individual and the specific haplotype for D2-D3 region.

${ }^{\mathrm{b}}$ Haplotype diversity $(h)$ and nucleotide diversity $(\pi)$ for each location; $n=$ number of individuals analyzed.

c Population sampled in three places with high infestation levels in the same field. 
morphism (SSCP) analysis. Each COI PCR reaction was conducted using a single adult female as template. For SSCP analysis, $5 \mu$ of $C O I$ PCR reaction was mixed with $5 \mu$ of loading dye (99\% formamide, $1 \% \mathrm{NaOH}$, and $1 \mathrm{M}$ bromophenol blue), denaturized for $10 \mathrm{~min}$ at $94^{\circ} \mathrm{C}$, and immediately placed on a cooler block until loading on a nondenaturing MDE Gel Solution (Cambrex, Rockland) as described by the manufacturer $(0.5 \mathrm{~mm}$ and $5 \%$ glycerol). Electrophoretic separations were carried out at $80 \mathrm{~V}$ and $4^{\circ} \mathrm{C}$ for $12 \mathrm{~h}$. After electrophoresis, haplotypes were visualized by DNA silver staining following the protocol described by Caetano-Anollés and Gresshoff (6). Nematodes from each Xiphinema population were tested in different gels. The commercial molecular DNA marker O'GeneRuler (Fermentas, Burlington, ON, Canada) and a nematode sample (reference haplotype) were included in each gel to compare band positions amongst all gels.

DNA sequencing. $C O I$ and $28 \mathrm{~S}$ rDNA PCR products were purified with the Geneclean turbo gel extraction kit (Q-BIOgene SA, Illkirch Cedex, France) according to the manufacturer's instructions and quantified using a Nanodrop spectrophotometer (Nanodrop Technologies, Wilmington, DE). Two samples from nematodes showing different $C O I$ SSCP patterns were cloned into the pGEM-T Easy vector and transformed into JM109 High Efficiency Cells (Promega Corporation, Madison, WI). Purified PCR products of the $28 \mathrm{~S}$ rDNA from individuals with different haplotypes were used for direct sequencing. Sequencing reactions were conducted in both directions using the same amplification primers for $28 \mathrm{~S}$ rDNA and vector universal primers for clones containing $C O I$ sequences. A terminator cycle sequencing-ready reaction kit (BigDye; Perkin-Elmer Applied Biosystems) was used according to the manufacturer's instructions. The resulting products were purified and run on a DNA multicapillary sequencer (Model 3130XL genetic analyzer; Applied Biosystems, Foster City, CA) at the STABVIDA sequencing facilities (Monte da Caparica, Portugal). The sequences of partial COI and $28 \mathrm{~S}$ rDNA of $X$. pachtaicum and $X$. index were deposited in the GenBank database under accession numbers HM921369 to HM921406 (Tables 1 and 2).

Data analysis. 28S rDNA and COI sequences from our Xiphinema populations and sequences deposited in GenBank were used for phylogenetic tree construction. $X$. diffusum was used as outgroup (AM086701 and AY601600). COI and D2-D3 sequences from GenBank from X. index (AY601628) and X. pachtaicum (GU222424, AY601607, and AY601606) were included in the analysis. The sequences for each gene were aligned with default parameters and manually edited using BioEdit (21). The best fit model of DNA evolution was obtained using the program jModeltest version 0.1.1 (38) and the Akaike Information Criterion (AIC) and was subsequently used in the phylogenetic analyses. The best models were TIM2 + I and TIM3 + G for COI and D2-D3, respectively. Phylogenetic analysis of the sequence data sets were performed with neighbor-joining (NJ) and maximum likelihood (ML) using PAUP* 4b10 (48), and Bayesian inference (BI) using MrBayes 3.1.2 (23). Support for each node was calculated using a bootstrap analysis with 1,000 and 100 replicates using a heuristic search for NJ and ML, respectively. BI analysis was initiated with a random starting tree and was run with four chains for $500 \times 10^{3}$ generations. The Markov chains were sampled at intervals of 100 generations. Two runs were performed for each analysis. The topologies were used to generate a $50 \%$ majority rule consensus tree.

Nucleotide $(\pi)$ and haplotype diversity $(h)$, were calculated for COI sequences using ARLEQUIN version 3.11 (15). The genetic structure of $X$. pachtaicum and $X$. index populations was analyzed using analysis of molecular variance (AMOVA) as implemented in ARLEQUIN, using the Tamura model to calculate the distance matrix. This model was most similar to that determined by jModeltest. AMOVA calculates the molecular variance and $\Phi$ statistics among and within populations, and the significance of the variance components is tested by permuting haplotypes among populations (16). Population pairwise $\Phi_{\mathrm{ST}}$ values were calculated using Tamura distances and corrected for multiple comparisons. Subsequently, we investigated whether grouping localities according to D.O. zones (group 1: Córdoba-IAS + Moriles-393; group 2: Jerez de la Frontera-500 + Trebujena-506 + Jerez de la Frontera-401) or to a north-south division (group 1: Córdoba-IAS + Moriles-393 + La Guardia-Rioja; group 2: Bollullos par del Condado-484 + Jerez de la Frontera-500+Trebujena506 + Jerez de la Frontera-401 + Frigiliana) would contribute significantly to the observed genetic variation for X. pachtaicum. For $X$. index, grouping was done according to country, D.O. zones (group 1: Morilles-393 + Montemayor-116 + Córdoba-Aulaga; group 2: Parteolla-NR4 + Trexenta-VNR) or to the north-south axis (group 1: Montemayor-116 + Córdoba-Aulaga + Moriles393; group 2: Rociana-474 + Jerez de la Frontera-499). Finally, a statistical parsimony haplotype network was constructed using the program TCS version 1.21 (8) to visualize intraspecific relationships between COI haplotypes.

\section{RESULTS}

Sequence analysis. In total, 89 individuals of $X$. pachtaicum were analyzed for sequence variation within the 443-bp mitochondrial COI gene amplicon (removing primers), yielding six different haplotypes (Table 1). Pairwise divergences between the COI sequences ranged from $0.2 \%$ ( 1 base substitution) to $2.3 \%$ (10 substitutions), most of them being third-base transversions. No insertions or deletions occurred between the sequences from $X$. pachtaicum. For $X$. index, 117 individuals were analyzed for sequence variation within the 418-bp mitochondrial COI gene amplicon (removing primers), yielding four different haplotypes (Table 2). For $X$. index, pairwise divergences between the COI sequences ranged from $0.2 \%$ (one base substitution) to $0.4 \%$ (two substitutions), most of them being third-base transversions. Also, no insertions or deletions occurred between the sequences of $X$. index.

For the D2-D3 expansion segment, the differences showed a pattern similar to that for $C O I$. The maximum differences for $X$. pachtaicum ranged from $0.1 \%$ (one base substitution) to $0.9 \%$ (seven substitutions) for an alignment of $760 \mathrm{bp}$ whereas, for $X$. index, the differences consisted of only one nucleotide difference in position 682 for the population Jerez de la Frontera-499. However, nucleotide position 127 presented an ambiguous nucleotide $(\mathrm{C} / \mathrm{T})$ in the majority of the studied populations.

Phylogenetic analysis. All haplotypes were grouped according to their respective Xiphinema sp. (Fig. 2). For X. pachtaicum, COI sequences were grouped into two low-supported clades, one with haplotypes PC and PB and another with haplotypes PA, PA1, PD, and PE (Fig. 2). Surprisingly, X. pachtaicum (GU222424) was highly differentiated $(23.3 \%, 106$ to 107 substitutions) from our $X$. pachtaicum sequences. COI haplotypes of $X$. index were pooled into one highly supported clade (Fig. 2). The nuclear D2D3 region nicely depicted each species, with one well-supported clade for $X$. pachtaicum and one for $X$. index.

Population genetic structure. AMOVA showed a pronounced structuring among populations in both species $\left(X\right.$. index: $\Phi_{\mathrm{ST}}=$ $0.66, P<0.0001 ; X$. pachtaicum: $\left.\Phi_{\mathrm{ST}}=0.88, P<0.0001\right)$. Populations of both species in most cases always contained a single haplotype (Fig. 3). Pairwise population comparisons for X. pachtaicum showed that most populations were significantly differentiated from each other, except for population Córdoba-IAS, which was strongly differentiated from Morilles-393 and La GuardiaRioja but not from the other populations (Table 3). No significant amount of variation could be explained by grouping $X$. pachtaicum populations according to D.O. zones $\left(38.53 \%, F_{\mathrm{CT}}=\right.$ $0.385, P=0.09)$. In contrast, a large amount of variation could be 
explained by grouping the populations according to a north-south axis $\left(61.43 \%, F_{\mathrm{CT}}=0.614\right)$, albeit at a borderline nonsignificant level $(P=0.053)$. For $X$. index, pairwise population comparisons showed that the strong differentiation was caused by Montemayor-116 and Trexenta-VRM populations, which were highly differentiated from each other and from all other populations (Table 4). Interestingly, the second Sardinian population (ParteollaNR4) was not differentiated from the other Spanish populations. In general, population differentiation was less pronounced in this species than in $X$. pachtaicum. Grouping $X$. index populations according to D.O zones, country, or north-south axis did not result in significant $F_{\mathrm{CT}}$ values (data not shown).

The intrafield variability study for both Xiphinema spp. (locality Moriles-393) (Tables 1 and 2) also showed a high homogeneity, because only one haplotype was found for each species: haplotypes PC and IA for $X$. pachtaicum and $X$. index, respectively.

Demographic history. The maximum parsimony network of $X$. pachtaicum shows that haplotypes $\mathrm{PB}$ and $\mathrm{PC}$ have accumulated mutations compared with the other haplotypes. These two haplotypes almost exclusively occur in the northern populations. However, one individual from Bollullos par del Condado (Huelva province), not included in this study because only a single individual was sampled, also contained the same haplotype (PC). The other four haplotypes differ in only one or two mutations, and were found in the southern populations. One exception is haplotype PA, which also occurred in the Córdoba-IAS population. For $X$. index, only one to two mutations occurred between the haplotypes, and haplotype IA was found in almost all populations sampled.

\section{DISCUSSION}

For plant-parasitic nematodes, intra- and interpopulation genetic diversity, as well as gene flow at various spatial scales, are poorly known (37) and differ between nematodes and sampled areas. $G$. pallida showed a high genetic structure coupled with isolation by distance in the Andean Cordillera but absence of genetic structure in agronomic areas (36). Another study found low genetic differentiation for $H$. schachtii between fields and regions (37). Research on some Meloidogyne spp. using different markers and sampling scales indicated a low differentiation in mitochondrial haplotypes (24) or a panmictic structure using amplified fragment length polymorphism markers (17). These different genetic structures preclude general conclusions for plant-parasitic nematode species and warrant individual studies for each species. A comparative population genetic structure between closely related species, as in our study, could help to better understand species distributions, connectivity between regions, and human influences in the actual species distribution.

The primary objective of this study was to determine the genetic variation and genetic differentiation in X. pachtaicum and $X$. index, two nematode species that are widespread in grapevinegrowing areas worldwide. These two species probably have different geographical origins, predominantly reproduce by parthenogenesis, and show low dispersal abilities. The strong genetic structuring observed in both Xiphinema spp. is in agreement with these biological characteristics. Nevertheless, the two species showed different levels of genetic diversity, with $X$. index exhibiting fewer haplotypes and mutations, despite the larger geographical sampled area. $X$. index probably originated in the Middle East and was later introduced in different Mediterranean areas $(4,51)$. If $X$. index has been introduced to Spain, then this introduction was widespread and most likely originated from the same source population, because the same haplotype (IA) was shared among almost all populations. In contrast, X. pachtaicum, one of the most widely distributed Xiphinema spp. in Europe (4), showed a large number of mutations between haplotypes $\mathrm{PB}$ and $\mathrm{PC}$ on the one hand and the other four haplotypes on the other hand. This,
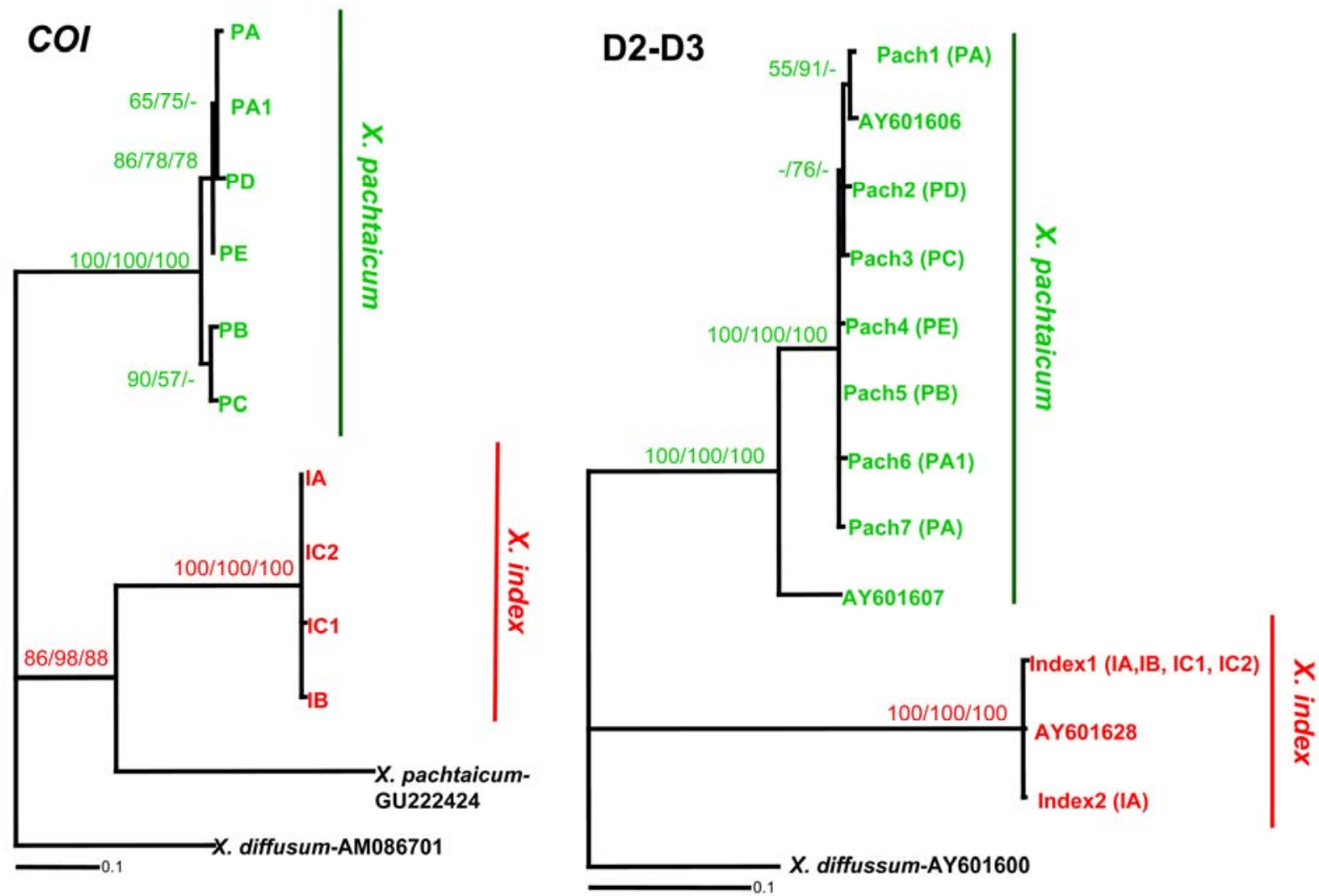

Fig. 2. Bayesian inference (BI) phylogenetic trees based on mitochondrial DNA COI and D2-D3 expansion segments of 28S for haplotypes detected in Xiphinema pachtaicum and $X$. index populations. Support values are represented on the tree as neighbor-joining (NJ), BI, or maximum likelihood (ML). Haplotype names are as in Tables 1 and 2. Names between parentheses are the individuals with a specific COI haplotype. 
together with the distribution of $\mathrm{PB}$ and $\mathrm{PC}$ in only the northern populations, indicates that these populations have experienced a different colonization history than the southern populations. This diversity may reflect a mix of original wild populations with introduced populations or different source populations from which the two areas were colonized.
The low diversity of haplotypes suggests that both $X$. pachtaicum and $X$. index have a recent origin in Spain. Their widespread distribution across Spain may then be the result of passive dispersal through agricultural activities (infested soil or infected plant-propagating material). This would explain the high similarity between Frigiliana and Rioja populations and some other

A

Cladogram X. pachtaicum-COI

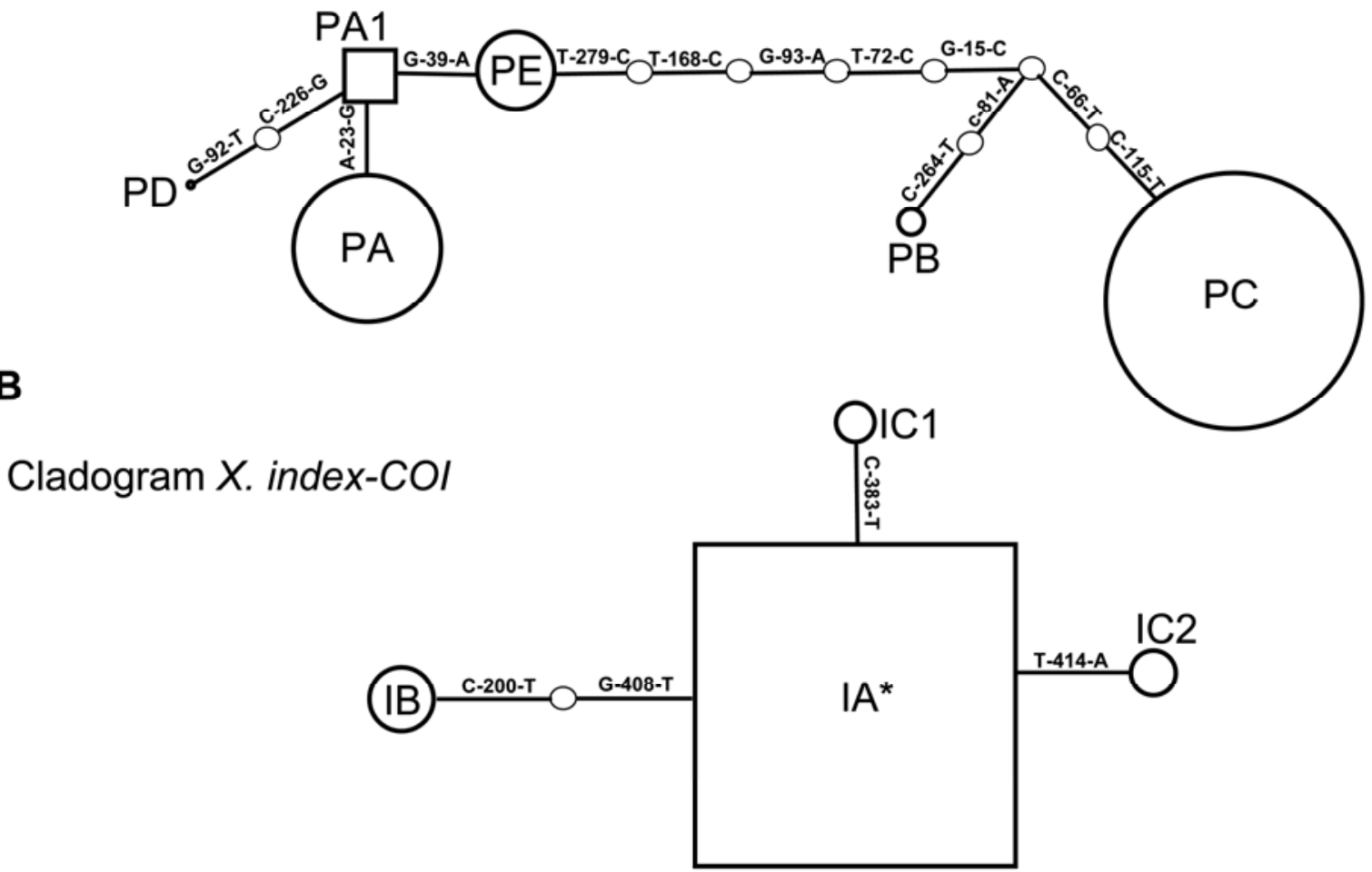

Fig. 3. Haplotype network for A, Xiphinema index and $\mathbf{B}$, X. pachtaicum inferred from mitochondrial DNA sequences after removing primer sequences. Each line in the network represents a single mutational change; $\bigcirc$ indicates a missing haplotype. Haplotype identifications are those given in Tables 1 and 2. Square box represents the older haplotype given by the program TCS. Haplotype IA $(*)$ is not in accordance with number of individuals.

TABLE 3. Populations pairwise $\Phi_{\mathrm{ST}}$ for Xiphinema pachtaicum using Tamura distance method ${ }^{\mathrm{a}}$

\begin{tabular}{|c|c|c|c|c|c|c|c|c|}
\hline Population & Cordoba-IAS & Moriles-393 & $\begin{array}{l}\text { La Guardia- } \\
\text { Rioja }\end{array}$ & Frigiliana & $\begin{array}{c}\text { Jerez de la } \\
\text { Frontera-401 }\end{array}$ & $\begin{array}{c}\text { Jerez de la } \\
\text { Frontera-500 }\end{array}$ & $\begin{array}{c}\text { Trebujena- } \\
506\end{array}$ & $\begin{array}{c}\text { Bollullos par del } \\
\text { Condado-484 }\end{array}$ \\
\hline Cordoba-IAS & - & - & - & - & - & - & - & - \\
\hline Moriles-393 & 0.80197 & - & - & - & - & - & - & - \\
\hline La Guardia-Rioja & 0.71221 & 0.00000 & - & - & - & - & - & - \\
\hline Frigiliana & 0.05882 & 1.00000 & 1.00000 & - & - & - & - & - \\
\hline Jerez de la Frontera-401 & 0.12213 & 0.98226 & 0.96717 & 0.13208 & - & - & - & - \\
\hline Jerez de la Frontera-500 & 0.39983 & 1.00000 & 1.00000 & 1.00000 & 0.83960 & - & - & - \\
\hline Trebujena-506 & 0.21311 & 1.00000 & 1.00000 & 0.00000 & 0.10112 & 1.00000 & - & - \\
\hline Bollullos par del Condado-484 & 0.28007 & 1.00000 & 1.00000 & 1.00000 & 0.59716 & 1.00000 & 1.00000 & - \\
\hline
\end{tabular}

a Significant pairwise distances after Bonferonni correction are indicated in bold.

TABLE 4. Populations pairwise $\Phi_{\mathrm{ST}}$ for Xiphinema index using Tamura distance method ${ }^{\mathrm{a}}$

\begin{tabular}{|c|c|c|c|c|c|c|c|}
\hline Population & Moriles-393 & Montemayor-116 & Cordoba-Aulaga & Jerez de la Frontera-499 & Rociana-474 & Porteolla-NR4 & Trexenta-VRM \\
\hline Moriles-393 & - & - & - & - & - & - & - \\
\hline Montemayor-116 & 0.86411 & - & - & - & - & - & - \\
\hline Cordoba-Aulaga & 0.00000 & 0.75000 & - & - & - & - & - \\
\hline Jerez de la Frontera-499 & 0.00000 & 0.75000 & 0.00000 & - & - & - & - \\
\hline Rociana-474 & 0.00000 & 0.75000 & 0.00000 & 0.00000 & - & - & - \\
\hline Porteolla-NR4 & 0.00000 & 0.75000 & 0.00000 & 0.00000 & 0.00000 & - & - \\
\hline Trexenta-VRM & 0.65397 & 0.63694 & 0.46087 & 0.46087 & 0.46087 & 0.46087 & - \\
\hline
\end{tabular}

a Significant pairwise distances after Bonferonni correction are indicated in bold. 
populations that are separated by high ranges of mountains and long distances $(\approx 1,000 \mathrm{~km}$ north to south). Consequently, human activities (49) or other passive dispersal agents (animals, birds, wind, and so on) (31) may be an important factor for the observed geographical distribution of these nematode species. None of the genetic differences among the grapevine-growing areas could be explained by extensive and continuous grapevine cultivation in the sampled geographic areas or by inadequate sanitation practices during long periods of time.

The low overall genetic variability within populations and strong genetic subdivision between Xiphinema populations is likely to be caused by the parthenogenic mode of reproduction, which is expected to reduce variation within and increase variation between populations. In the absence of gene flow, local selective sweeps will remove variation within populations but will not remove variation between populations (42). The pronounced genetic structure indicated by AMOVA suggests an overall low gene flow among our Xiphinema populations. This result agrees with other $X$. index phylogeographic studies using more variable markers (microsatellites), in which no isolation by distance was observed at the grapevine field scale but a strong differentiation among sampling points within the same grapevine field was detected (52). Villate et al. (52) suggest that this pattern is consistent with the clonal reproductive mode and the limited capacities of active dispersal of Xiphinema spp. leading to a patchy spatial distribution within grapevine fields $(52,53)$. The lack of intrafield variability in our study is probably the result of using a mitochondrial gene instead of highly variable microsatellites, as were used by Villate et al. (52). Mitochondrial markers (CytB) used in other studies also showed large homogeneity in Western Europe (51).

Next to clonality and low dispersal, a strong genetic structuring among populations may also be explained by extinction and recolonization events with few individuals. These colonizationextinction dynamics may produce distinct genetic differentiation at very small geographical scales, as has been demonstrated in free-living rhabditid nematodes inhabiting ephemeral resources $(3,10,13,44)$. However, the Xiphinema populations here are not ephemeral and, in view of their limited dispersal ability and widespread distribution across large geographic distances, the effects of metapopulation dynamics will probably be unimportant. Additionally, an extinction-recolonization model would be difficult to reconcile with the mix of highly differentiated haplotypes (PA and $\mathrm{PB})$ in Córdoba.

Our second aim was to investigate the molecular identification of both species using the COI and D2-D3 rDNA fragments. Molecular discrimination among species in the X. americanum group is very important because some species are known to be vectors of plant viruses (50). The correspondence of tree topologies from mitochondrial and nuclear genes has been used to delineate cryptic nematode species (12). In our findings, both Xiphinema spp. are well separated by the two molecular markers, which is in agreement with a broader phylogeny of the family Longidoridae (19). Although COI did not show enough resolution to distinguish among the majority of the $X$. americanum species complex, it was useful in separating $X$. simile (AM086708, AM0867113), X. pachtaicum (AM086710), and X. americanum from Portugal (AM086709) (28). Nevertheless, sequence AM086710 of X. pachtaicum was considered to be a pseudogene (indicated in the National Center for Biotechnology Information) and clearly differed from all the sequences in the present study. Surprisingly, COI sequences obtained by Kumari et al. (25) from specimens collected in the Czech Republic differ in as much as 106 to 107 nucleotides with our COI sequences. In our study, X. pachtaicum was identified using morphological, morphometrical, and molecular data for each nematode population. All our data agree with measurements from original descriptions as well as with other molecular markers such as D2-D3 deposited in
GenBank (AY601606). Additionally, internal transcribed spacer (ITS) 1 sequences from some of our populations also agree with the ITS1 sequences deposited in the GenBank (AY430178) (19). In addition, another D2-D3 sequence (AY601607) assigned to $X$. pachtaicum from Eastern Europe (Moldavia) suggests that close morphometrical species may be present in this region and, for this reason, additional sequences from the same population may clarify $X$. pachtaicum species definition. In view of the possible problems with $C O I$ (pseudogenes and low resolution), the addition of the D2-D3 region of the 28S rDNA may provide a reliable tool to correctly identify $X$. pachtaicum and differentiate it from $X$. index.

In summary, this work represents the first population genetic study of two worldwide distributed plant-parasitic nematode species co-infesting similar crops and habitats using the COI gene. Several conclusions can be drawn from a phytopathological point: (i) both Xiphinema spp. showed low levels of molecular diversity at the intrapopulation level; however, this diversity was lower in $X$. index than $X$. pachtaicum; (ii) $X$. pachtaicum populations in Spain have two distinct pools of origin; (iii) populations of both Xiphinema spp. had a strong genetic structure which is most likely the result of their clonal reproduction; and (iv) $\mathrm{COI}$ and $28 \mathrm{~S}$ regions are suitable diagnostic markers for both Xiphinema spp.

\section{ACKNOWLEDGMENTS}

This research is a part of the Ph.D. project of C. Gutiérrez-Gutiérrez and was supported by grants P06-AGR-01360 from Consejería de Innovación Ciencia y Empresa of Junta de Andalucía and AGL200906955 from Ministerio de Ciencia e Innovación of Spain and the European Social Fund. We thank J. Martín Barbarroja and G. León Ropero from IAS-CSIC for excellent technical assistance, R. M. JiménezDíaz and J. A. Navas-Cortés (IAS-CSIC) for critically reading the manuscript prior to submission; and anonymous reviewers for editorial improvement.

\section{LITERATURE CITED}

1. Arias, M. 1974. Las especies de Xiphinema (Nematoda: Dorylaimida) en los cultivos frutales. Bol. R. Soc. Esp. Hist. Nat. Biol. 72:153-163.

2. Arias, M., and Fresno, J. 1994. Agroecological characterization of Xiphinema index in Spain. EPPO Bull. 24:403-411.

3. Barrière, A., and Félix, M. A. 2005. High local genetic diversity and low outcrossing rate in Caenorhabditis elegans natural populations. Curr. Biol. 15:1176-1184.

4. Brown, D. J. F., and Taylor, C. E. 1987. Comments on the occurrence and geographical distribution of longidorid nematodes in Europe and the Mediterranean region. Nematol. Mediterr. 15:333-373.

5. Brown, D. J. F., Halbrendt, J. M. Jonez, A. T., Taylor, C. E., and Lamberti, F. 1994. An appraisal of some aspects of the ecology of nematode vectors of plant viruses. Nematol. Mediterr. 22:253-263.

6. Caetano-Anollés, G., and Gresshoff, P. M. 1994. Staining nucleic acids with silver: An alternative to radioisotopic and fluorescent labeling. Promega Notes Mag. 45:13.

7. Castillo, P., Vovlas, N., Subbotin, S., and Troccoli, A. 2003. A new root-knot nematode, Meloidogyne baetica n. sp. (Nematoda: Heteroderidae), parasitizing wild olive in Southern Spain. Phytopathology 93:1093-1102.

8. Clement, M., Posada, D., and Crandall, K. A. 2000. TCS: a computer program to estimate gene genealogies. Mol. Ecol. 9:1657-1660.

9. Coomans, A., Huys, R., Heyns, J., and Luc, M. 2001. Character analysis, phylogeny, and biogeography of the genus Xiphinema Cobb, 1973 (Nematoda, Longidoridae). In: Annales du Musée Royal de l'Afrique Centrale (Zoologie), Vol. 287. Tervuren, Belgique.

10. Cutter, A. D., Félix, M. A., Barrière, A., and Charlesworth, D. 2006. Patterns of nucleotide polymorphism distinguish temperate and tropical wild isolates of Caenorhabditis briggsae. Genetics 173:2021-2031.

11. Decraemer, W., and Robbins, R. T. 2007. The who, what and where of Longidoridae and Trichodoridae. J. Nematol. 39:295-297.

12. Derycke, S., Remerie, T., Vierstraete, A., Backeljau, T., Vanfleteren, J., Vincx, M., and Moens, T. 2005. Mitochondrial DNA variation and cryptic speciation within the free-living marine nematode Pellioditis marina. Mar. Ecol. Prog. Ser. 300:91-103. 
13. Derycke, S., Van Vynckt, R., Vanoverbeke, J., Vincx, M., and Moens, T. 2007. Colonization patterns of Nematoda on decomposing algae in estuarine environment: Community assembly and genetic structure of the dominant species Pellioditis marina. Limnol. Oceanogr. 52:992-1001.

14. ECBOL web (European Consortium for the Barcode of Life). http://www.ecbol.org.

15. Excoffier, L., Laval, G., and Schneider, S. 2005. Arlequin ver. 3.0: An integrated software package for population genetics data analysis. Evol. Bioinf. 1:47-50.

16. Excoffier, L., Smouse, P., and Quattro, J. 1992. Analysis of molecular variance inferred from metric distances among DNA haplotypes: Application to human mitochondrial DNA restriction data. Genetics 131:479-491.

17. Fargette, M., Berthier, K., Richaud, M., Lollier, V., Franck, P., Hernandez, A., and Frutos, R. 2010. Crosses prior to parthenogenesis explain the current genetic diversity of tropical plant-parasitic Meloidogyne species (Nematoda: Tylenchida). Infect. Genet. Evol. 10:807-814.

18. Flegg, J. J. M. 1967. Extraction of Xiphinema and Longidorus species from soil by a modification of Cobb's decanting and sieving technique. Ann. Appl. Biol. 60:429-437.

19. Gutiérrez-Gutiérrez, C., Castillo, P., Cantalapiedra-Navarrete, C., Landa, B. B., and Palomares-Rius, J. E. 2011. Prevalence, polyphasic identification, and molecular phylogeny of dagger and needle nematodes infesting vineyards in southern Spain. Eur. J. Plant Pathol. 129:427-453.

20. Gutiérrez-Gutiérrez, C., Palomares-Rius, J. E, Cantalapiedra-Navarrete, C., Landa, B. B., Esmenjaud, D., and Castillo, P. 2010. Molecular analysis and comparative morphology to resolve a complex of cryptic Xiphinema species. Zool. Scr. 39:483-498.

21. Hall, T. A. 1999. BioEdit: A user-friendly biological sequence alignment editor and analysis program for windows 95/98/NT. Nucleic Acids Res. 41:95-98.

22. Hu, M., Chilton, N. B., Zhu, X., and Gasser, R. B. 2002. Single-strand conformation polymorphism-based analysis of mitochondrial cytochrome c oxidase subunit 1 reveals significant substructuring in hookworm populations. Electrophoresis 23:27-34.

23. Huelsenbeck, J. P., and Ronquist, F. 2001. MrBAYES: Bayesian inference of phylogenetic trees. Bioinformatics 17:754-755.

24. Hugall, A., Moritz, C., Stanton, J., and Wolstenholme, D. R. 1994. Low, but strongly structured mitochondrial DNA diversity in root knot nematodes (Meloidogyne). Genetics 136:903-912.

25. Kumari, S., Decraemer, W., De Luca, F., and Tiefenbrunner, W. 2010. Cythocrome c oxidase subunit 1 analysis of Xiphinema diversicaudatum, $X$. pachtaicum, X. simile and X. vuittenezi (Nematoda, Dorylaimida). Eur. J. Plant Pathol. 127:493-499.

26. Lamberti, F., Roca, F, and Agostinelli, A. 1988. On the identity of Xiphinema americanum in Chile with a key to the Xiphinema species occurring in Chile. Nematol. Mediterr. 16:67-68.

27. Lamberti, F., and Siddiqi, M. R. 1977. Xiphinema pachtaicum. Descriptions of plant parasitic nematodes. In: Parasitology, Vol. Set 7, No. 94. C. I. H., ed. St. Albans, England.

28. Lazarova, S. L., Malloch, G., Oliveira, C. M. G., Hübschen, J., and Neilson, R. 2006. Ribosomal and mitochondrial DNA analyses of Xiphinema americanum-group populations. J. Nematol. 38:404-410.

29. Martelli G. P., and Savino, V., 1990. Fanleaf degeneration. Pages 48-49 in: Compendium of Grape Diseases. R. C. Pearson and A. Goheen, eds. American Phytopathological Society Press, St. Paul, MN.

30. McDonald, B. A., and Linde, C. 2002. Pathogen population genetics, evolutionary potential, and durable resistance. Annu. Rev. Phytopathol. 40:349-379.

31. McNamara, D. G., and Flegg, J. J. M. 1981. The distribution of virus vector nematodes in Great Britain in relation to past and present natural vegetation. Pages 225-235 in: Pests, Pathogens and Vegetation. J. M. Thresh, ed. Pitman, London.

32. Moreno, I. M., Malpica, J. M., Díaz-Pendón, J. A., Moriones, E., Fraile, A., and García-Arenal, F. 2004. Variability and genetic structure of the population of watermelon mosaic virus infecting melon in Spain. Virology 318:451-460.

33. Navas, A., Bello, A., and Arias, M. 1988. Ecology and potential distribution of Xiphinema diversicaudatum and X. pachtaicum (Nematoda: Longidoridae) in continental Spain. Nematologica 34:314-330.
34. Palomares-Rius, J. E., Subbotin, S. A., Liébanas, G., Landa, B. B., and Castillo, P. 2009. Eutylenchus excretorius Ebsary Eveleigh, 1981 (Nematoda: Tylodorinae) from Spain with approaches to molecular phylogeny of related genera. Nematology 11:343-354.

35. Phillips, D. V., Carbone, I., Gold, S. E., and Kohn, L. M. 2002. Phylogeography and genotype-symptom associations in early and late season infections of canola by Sclerotinia sclerotiorum. Phytopathology 92:785793.

36. Picard, D., and Plantard, O. 2006. What constitutes a population for the plant parasitic nematode Globodera pallida in its native area (Peru)? Int. J. Parasitol. 36:115-122.

37. Plantard, O., and Porte, C. 2004. Population genetic structure of the sugar beet cyst nematode Heterodera schachtii: A gonochoristic and amphimictic species with highly inbred but weakly differentiated population. Mol. Ecol. 13:33-41.

38. Posada, D. 2008. jModelTest: Phylogenetic model averaging. Mol. Biol. Evol. 25:1253-1256.

39. Quader, M., Riley, I. T., and Walker, G. E. 2003. Spatial and temporal distribution patterns of dagger (Xiphinema spp.) and root lesion (Pratylenchus spp.) nematodes in South Australia vineyard. Australas. Plant Pathol. 32:81-86

40. Restrepo, S., Velez, C. M., Duque, M. C., and Verdier, V. 2004. Genetic structure and population dynamics of Xanthomonas axonopodis pv. manihotis in Colombia from 1995 to 1999. Appl. Environ. Microbiol. 70:255-261.

41. Robbins, R. T. 1993. Distribution of Xiphinema americanum and related species in North America. J. Nematol. 25:344-348.

42. Rydholm, C., Szakacs, G., and Lutzoni, F. 2006. Low genetic variation and no detectable population structure in Aspergillus fumigatus compared to closely related Neosartorya species. Eukaryot. Cell 5:650-657.

43. Seinhorst, J. W. 1966. Killing nematodes for taxonomic study with hot f.a. 4:1. Nematologica 12:178.

44. Sivasundar, A., and Hey, J. 2005. Sampling from natural populations using RNAi reveals high outcrossing and population structure in Caenorhabditis elegans. Curr. Biol. 15:1598-1602.

45. Stukenbrock, E. H., and McDonald, B. A. 2008. The origins of plant pathogens in agro-ecosystems. Annu. Rev. Phytopathol. 46:75-100.

46. Subbotin, S. A., Madani, M., Krall, E., Sturhan, D., and Moens, M. 2005. Molecular diagnostics, taxonomy, and phylogeny of the stem nematode Ditylenchus dipsaci species complex based on the sequences of the internal transcribed spacer-rDNA. Phytopathology 95:1308-1315.

47. Subbotin, S. A., Ragsdale, E. J., Mullens, T., Roberts, P. A., MundoOcampo, M., and Baldwin, J. G. 2008. A phylogenetic framework for root lesion nematodes of the genus Pratylenchus (Nematoda): Evidence from $18 \mathrm{~S}$ and D2-D3 expansion segments of 28S ribosomal RNA genes and morphological characters. Mol. Phylogenet. Evol. 48:491-505.

48. Swofford, D. L. 2003. PAUP*: Phylogenetic Analysis Using Parsimony (*and other methods), version 4.0b 10. Sinauer Associates, Sunderland, MA.

49. Taylor, C. E. 1986. Quarantine and legislation. Pages 451-459 in: Cyst Nematodes. F. Lamberti and C. E. Taylor, eds. Plenum Press, New York and London.

50. Taylor, C. E., and Brown, D. J. F. 1997. Nematode Vectors of Plant Viruses. CAB International, Wallingford, UK

51. Villate, L. 2008. Origine, variabilité et gestion des populations de Xiphinema index, le nématode vecteur du Grapevine fanleaf virus (GFLV). Université de Rennes 1, Rennes, France.

52. Villate, L., Esmenjaud, D., Van Helden, M., Stoeckel, S., and Plantard, O. 2010. Genetic signature of amphimixis allows for the detection and fine scale localization of sexual reproduction events in a mainly parthenogenetic nematode. Mol. Ecol. 19:856-873.

53. Villate, L., Fievet, V., Hanse, B., Delemarre, F., Plantard, O., Esmenjaud, D., and van Helden, M. 2008. Spatial distribution of the dagger nematode Xiphinema index and its associated Grapevine fanleaf virus in French vineyard. Phytopathology 98:942-948.

54. Zhou, Z., Sakaue, D., Wu, B., and Hogetsu, T. 2007. Genetic structure of populations of the pinewood nematode Bursaphelenchus xylophilus, the pathogen of pine wilt disease, between and within pine forests. Phytopathology 97:304-310 